\title{
Impact of Time Budget Pressure, Locus of Control, Independence, Professional Skeptisism and Audit Judgement on Audit Quality in Indonesian
}

\author{
Swarmilah Hariani \\ Universitas Mercu Buana
}

\begin{abstract}
This study aims to analyze the impact of Time Budget Pressure, Locus of Control, Independent, Professional Skepticism and Audit Judgment on Audit Quality (empirical study of Indonesian Supreme Audit Institution). This study uses primary data and uses a questionnaire for data collection. The sampling technique used was simple random sampling, namely 80 auditors. The method of collecting data uses a survey method by sending questionnaires directly to the respondent and the analytical method using multiple linear regression analysis. The results of this study indicate that time budget pressure has a negative effect on audit quality. Locus of control and independence have a positive effect on audit quality. Professional skepticism, Audit Judgment shows a positive effect on audit quality.
\end{abstract}

Keywords: Audit Quality, Time Budget Pressure, Locus of Control, Independent, Professional Skepticism, Audit Judgment

DOI: $10.7176 / \mathrm{EJBM} / 11-27-10$

Publication date:September $30^{\text {th }} 2019$

\section{Introduction}

Auditors are required to carry out their work professionally so that the audit report produced will be of high quality. According to DeAngelo (1981) where an auditor finds and reports about existence a violation in the client's accounting system. The quality of the auditor's work relates to the quality of expertise, the timeliness of completion of work, the adequacy of proof of examination, and the attitude of professionality in completing work. Audit quality is how appropriate the audit is with auditing standards (Watkins et al, 2004). The auditor must carry out his work professionally. Provide accurate and reliable information for decision making (Davidson and Neu, 1993).

An example in Indonesia of audit quality is the case of the Ministry of Finance's financial report in 2016 which alleged an element of bribery in the audit. On August 16, 2017 Former Inspector General of the Ministry of Rural Development and Transmigration (Inspector General of the Ministry of Education and Culture) Sugito and his men Jarot Budi Prabowo were charged with bribing two auditors from the Indonesian Supreme Audit Institution (BPK-RI). Sugito and Jarot are said to have given Rp. 240 million to two BPK-RI auditors in order to obtain unqualified opinion on the financial statements of the Ministry of Village of PDTT for Fiscal Year 2016, according to the indictment in the Corruption Court (source kompas.com 10/11/2017).

The bribe was given to the person in charge of inspecting the examination objects in Jakarta and other areas. The BPK-RI examination results qualified opinion (WDP). With the hope of obtaining unqualified opinion (WTP) Opinion General Ministry of Villages, Disadvantaged Areas and Transmigration (Ministry of PDTT) financial report for the 2016 fiscal year. In the 2016 Board of Directors Ministry of PDTT of Financial Report,

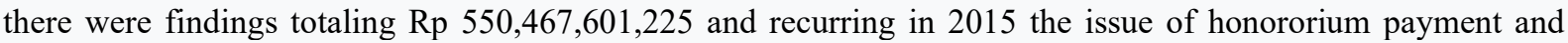
operational cost assistance to professional facilitators in 2016 in which the Ministry of PDTT had not fully implemented the recommendations (source kompas.com 10/11/2017).

From the above phenomena, it can be seen that in practice corruption cases involve members of the BPK-RI, where audit opinions from the BPK-RI can be manipulated even though there are already standard standards in giving opinions on a financial report. This is a reduction in audit quality, which has a large impact on public confidence in the professionalism of financial auditors, especially the BPK-RI. Where the BPK-RI should be an independent public trust pillar and can provide guarantees for the relevance and reliability of state financial reporting. The information contained in the Regional Government Financial Statements must be useful and appropriate for the needs of stakeholders, free from misstatements of information that can mislead users of financial statements (Hari, 2013; Nurlis, 2018)

This problem is important to examine because it sees the phenomenon of the low quality of the work of the auditor. Time Budget Pressure, Locus of Control, Independence, Professional Skepticism and Audit Judgment are important factors that must be considered by the auditor to guarantee the quality of the work of the auditor. Quality report demands with a limited time budget are of course a separate pressure for the auditor.

According to Wagoner (1991) if time allocation for assignments not enough, the auditor might compensate with work quickly and only complete important tasks only so that it might produce ineffective performance. 
With no effective performance performed by the auditor due to the time budget pressure, this will affect the quality of the audit conducted by auditor.

According to Coram et, al., (2004) auditing procedures are mostly carried out by auditors in time pressure conditions. Auditors generally view that performance evaluation and career promotion within the scope of the audit are closely related to the ability to complete audit assignments accordingly with the time and budget. At the same time they are also required to equipping all audit assignments and procedures as a basis for giving opinions regarding the fairness of financial statements. Behavior this is what causes dilemma for auditors between completing audit assignments in accordance with the budget given time with audit quality according to professional standards that must be adhered to (Kaplan, 1995).

Liayanarachchi and McNamara (2007), stated that the time budget significantly influences audit quality. When an auditor experiences time pressure in conducting an audit due to a low time budget, the tested transaction tends to be small. So the results cannot represent the true condition of the client. Time budget pressure is also an important factor affecting audit quality. With the time budget pressure forces the auditor to complete the audit task as soon as possible, in accordance with a predetermined time budget. So that if the auditor has a low time budget pressure can result in a decrease in audit quality and vice versa with a high time budget pressure can improve audit quality, so that audit quality is maintained properly.

Locus of control is the level where someone is sure that they are determinants of their destiny itself, consists of two types of locus of control namely internal locus of control and external locus of control. Internal locus of control are individuals who believe they are is in control of anything what happened to them while external locus of control is an individual who believes that whatever happens to themselves are controlled by outside forces like luck or opportunity (Judge and Robbins 2009: 138).

What is the auditor must be independent of the client or the information submitted by the client. The independence of auditors towards clients is a difficult thing to do observed by other parties. There are no other parties other than auditors and clients can ascertain how independent the auditor is in an assignment (Kinney, 1999).

Audit quality is determined by two things, namely competence and independence. Good quality audits require both competence (expertise) and independence. These qualities have direct effects on actual audit quality, as well as potential interactive effects. In addition, financial statement users' quality audit is a function of their concept of both auditor independence and expertise (AAA Financial Accounting Standard Committee 2000). Independence avoids possible relationships disrupting the auditor's objectivity. An auditor must not be biased, prejudiced, and must try avoid conflicts of interest. Therefore an auditor both individually and Institutions must be free from all things/ disturbances that can eventually affect the process of carrying out the audit as well as the results of audit reporting, so that the results and reporting of audits carried out will be in accordance with professional standards and a code of ethics has been established (Messier et al, 2005).

According to Boynton (2002: 103) accuracy and accuracy requires the auditor to carry out professional skepticism, that is an attitude of a critical thinking auditor always with audit evidence question and evaluate of the audit evidence, and being careful in the assignment, not careless inside do checks and have firmness in carrying out responsibility answer. Nearon (2005) in Mansur (2007), also stated the same thing that if the auditor fails to use attitudes skeptical or the application of skepticism not in accordance with the conditions at the time inspection, then the audit opinion issuance of ineffective and not have good audit quality.

According to Mulyadi (2002) audit judgment is auditor policy in determining opinions regarding the results of the audit which refers to the formation of an idea, opinion or estimate about an object, event, status, or other type of event. Hogarth (1992) judgment as a cognitive process is decision-making behavior. In making a judgment, the auditor will collect a variety of relevant evidence at different times and then integrate information from the evidence.

\section{Theory and Hypothesis Development}

\subsection{Teori $X$ and $Y$ McGregor}

McGregor (1960) two views on humans, namely theory X (negative) and theory Y (positive). Auditors who are included in type $\mathrm{X}$ if they receive obedience pressure and complex audit assignments can make inappropriate judgments. The auditor unable to carry out his responsibilities as an auditor, prefer to put security above all factors associated with work, so when get the pressure of obedience and face complex tasks so he will tend to look for ways that are safe and even dysfunctional in making judgment. While auditors included in type $\mathrm{Y}$ can responsible for his duties and remain professional in carry out duties as an auditor. The auditor will not be affected even though he is get compliance pressure and face complex audit tasks, so can make a better and more appropriate judgment.

\subsection{Goal Setting Theory}

Edwin Locke (1978) suggests that the intention to achieve a goal is a source of motivation main work. More 
purpose specific, difficult and challenging will result in higher performance and good compared to unclear goals, such as easy goals or there is no purpose at all. If the manager knows what the goal really is achieved by them, then they will be more motivated to mobilize businesses that can improve their performance (Locke and Latham, 1991). An auditor who can understand what is his purpose and what he is expect the results of its performance, will not be deviant when it gets pressure from superiors or entities examined and complex audit tasks. An understanding of its objectives can help the auditor make an audit good judgment.

\subsection{Audit Quality}

Goetsh and Davis (1994) Quality is a thing dynamic conditions related to products, services, people, processes and fulfilling environment that fulfills or exceed expectations. At the moment the concept of quality is a word used universally and has become the success of a business. Audit quality can be interpreted as good or not inspection that has been carried out by auditor. Based on Professional Accountant Standards Public (2017) audit what the auditor does is said to be of quality, if it meets the requirements or auditing standards. Standard auditing includes quality professional, independent auditor, judgment used in conducting audits and preparation of audit reports.

\subsection{Impact of Time Budget Pressure on Audit Quality}

Coram et al (2003) show there is a decrease in audit quality at auditors who are under pressure due to a very time budget strict. This kind of situation is special challenges for auditors, because in the complexity of the task that is increasingly high and limited time budget, they are required to produce reports quality audit. A pressure can affect someone's behavior in taking decision, change the strategy already used and can also limit the process information. This kind of pressure can reduce audit quality and reports financial results. Time pressure this budget is not only felt by seniors auditor and junior auditor, but also by manager and colleague (Arrens, et all. 2005).

\subsection{Impact of Locus of Control on Audit Quality}

According to Donelly et al (2003) locus of control as a person's beliefs regarding causes of people's achievements or failuresin his work. Locus of control consists of internal locus of control as well external locus of control. Bernardi (2003) mentions that someone is capable balancing external and internal locus of control tends to avoid feeling depressed. The internal locus of control is dominant in one's self makes the individual try better to reach success. Based on the results of research obtained by Hyatt and Prawitt (2001) Locus of Control is estimated to be able affect auditor performance for internal auditors in addition to groups external audit. As stated in Patten (2005), department internal audit of companies by reflecting on world trends public accountants, are experimenting with reviewing internal ways auditors provide audit services for the company, so with observe the potential role of the audit structure and Locus of Control inside internal audit department, it will be able to enrich knowledge and insight for the audit department to improve audit quality.

\subsection{Impact of Independensi on Audit Quality}

Independent means in carrying out work for the sake of interest general is not justified in favoring anyone's interests and is not easy influenced. Second general standard (SA section 220 in SPAP, 2011) mention that in all matters relating to the engagement, independence in mental attitude must be maintained by the auditor. Next in Mayangsari (2003), American Institute of Certified Public Accountans (AICPA) states that independence is an ability to act based on integrity and objectivity. From the description above, independence is the attitude of a person to act honest, impartial, and report findings based solely on evidence which is obtained.

\subsection{Impact of Skeptisisme Profesional on Audit Quality}

Auditors' professional skepticism or auditor's doubts about statements and client information both verbally and in writing are part of audit process. In SPAP, 2001 (SA section 230 p. 230. 2) it is stated that what is meant by professional auditor skepticism is an attitude that is includes the mind that always questions and evaluates critical of audit evidence, this is related to audit quality. The auditor's professional skepticism is implied inside the literature with the auditor's obligation to evaluate possibilities the occurrence of material fraud or abuse of authority occurs within the client company (Loebbecke et al 1989)

\subsection{Impact of Audit Judgement on Audit Quality}

Audit judgment is a decision issued by the auditor, Audit judgment has an important role in forming audit opinion (Iskandar, 2010). Making audit judgment requires expertise acquired through long learning the basis of audit science is obtained through campus learning, stating that knowledge can influence a person's judgment auditor. If an auditor has high knowledge, then judgment will given the better. Besides knowledge, experience can also influence the ability of an auditor to give judgment by predicting fraud that happened in the company. 
From this experience the auditor can learn how, how to make a judgment (Wibowo, 2011).

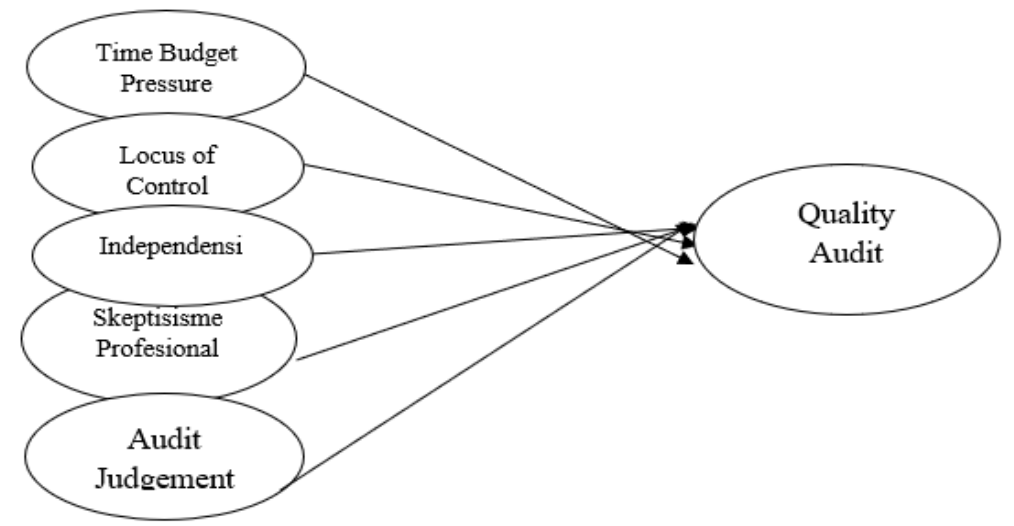

Figure 1 Research Framework

\section{Research Methodology}

In this study, the tool used to collect primary data was a questionnaire. The scale used in this study is the Likert scale. The population in this study are auditors who work in the Audit Board of the Republic of Indonesia. In the population there are criteria used as a consideration for determining the sample so that the sampling technique with non-probability method used is sampling (purposive sampling). The researcher took a sample of 80 functional examining officials at the Republic of Indonesia Supreme Audit Agency. The data analysis method used in this study is multiple regression analysis with the help of SPSS Version 23.

\section{Result Analysis}

Table I: Normality Test Results

One-Sample Kolmogorov-Smirnov Test

\begin{tabular}{|ll|r|}
\hline & & Unstandardized Residual \\
\hline $\mathrm{N}$ & & 80 \\
Normal Parameters ${ }^{\mathrm{a}, \mathrm{b}}$ & Mean &, 0000000 \\
& Std. Deviation & 3,01212738 \\
Most Extreme & Absolute &, 088 \\
Differences & Positive &, 088 \\
& Negative &,- 075 \\
Test Statistic & &, 088 \\
Asymp. Sig. (2-tailed) & &, $190^{\mathrm{c}}$ \\
\hline
\end{tabular}

Source: SPSS Version 23

From table I above shows the significance value (Asymp Sig 2 tailed) of 0.190, it can be concluded that the residual value is normally distributed. In addition, the normality test can also be done with the distribution of PPlots. The normality test on the P-Plot graph can be seen in the following figure 2:

Figure 2 P-P Normality Test Plot

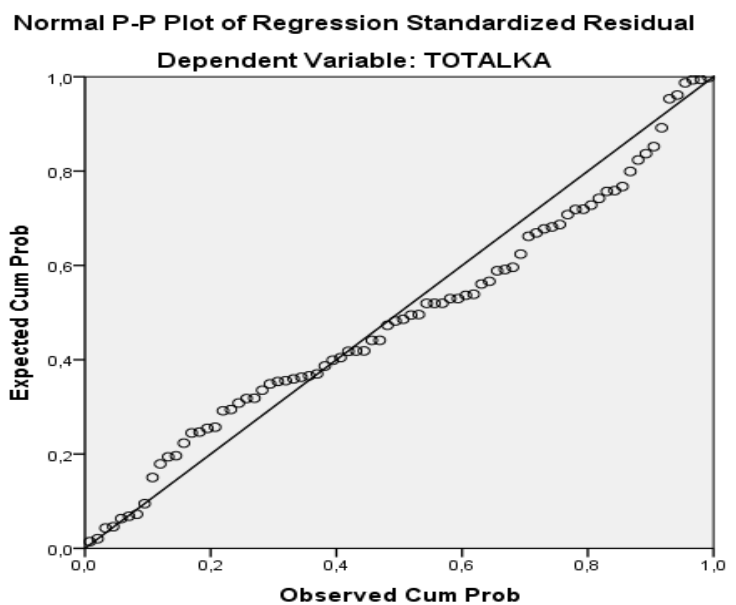

Source: SPSS Version 23 
Based on figure 2 the normal p-plot graph shows the points spread around the diagonal line, the residual value is normally distributed.

Table 2: Multicollinearity Test Results

\begin{tabular}{|c|c|c|c|c|c|c|}
\hline \multicolumn{7}{|c|}{ Coefficients $^{\mathrm{a}}$} \\
\hline \multirow{2}{*}{\multicolumn{2}{|c|}{ Model }} & \multicolumn{2}{|c|}{ Unstandardized Coefficients } & \multirow{2}{*}{$\begin{array}{c}\text { Standardized } \\
\text { Coefficients } \\
\text { Beta } \\
\end{array}$} & \multicolumn{2}{|c|}{ Collinearity Statistics } \\
\hline & & B & Std. Error & & Tolerance & VIF \\
\hline \multirow[t]{6}{*}{1} & (Constant) & 2,360 & 5,246 & & & \\
\hline & TOTALTBP &,- 302 & ,145 &,- 163 & ,973 & 1,027 \\
\hline & TOTALLOC & ,489 & ,096 & ,447 & ,768 & 1,302 \\
\hline & TOTALIDP &, 816 &, 173 & ,421 &, 745 & 1,342 \\
\hline & TOTALSP &, 022 &, 092 &, 019 & ,939 & 1,065 \\
\hline & TOTALAJ &,- 013 &, 075 &,- 014 & ,932 & 1,073 \\
\hline
\end{tabular}

Based on Table 2, it can be seen that the Tolerance value for the Time budget pressure (X1) variable is 0.973 , locus of control (X2) is 0.768 , Independence (X3) is 0.745 , Professional Skepticism (X4) is 0.939, and Audit Judgment (X5) of 0.932 While the value of VIF (Variance Inflation Factor) for time budget pressure variable (X1) is 1.027, locus of control (X2) is 1.302, Independence (X3) is 1.342, Professional Skepticism (X4) is equal to 1,065 , and Audit Judgment (X5) is 1,073 .

Figure 3 Heteroscedasticity Test Results

Scatterplot

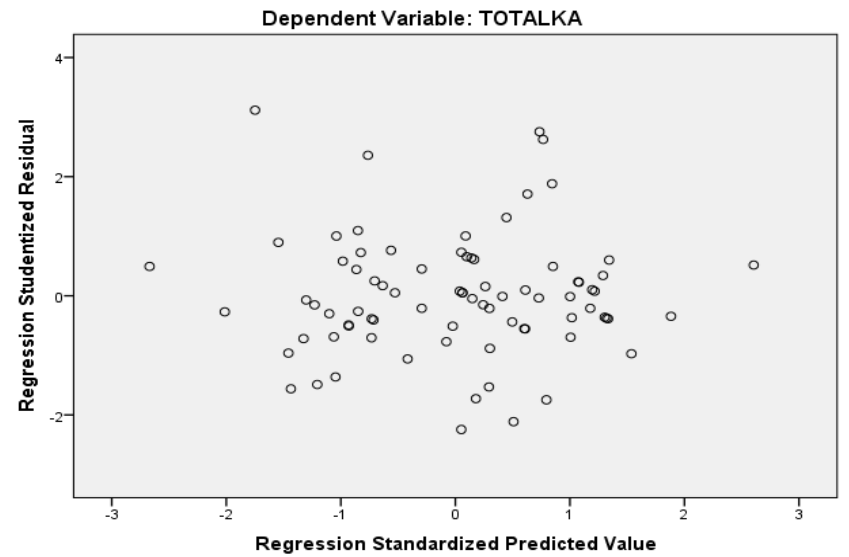

Source: SPSS Version 23

The following glejser test can be seen in table 3 below:

Table 3: Heteroscedasticity Test Results

Coefficientsa

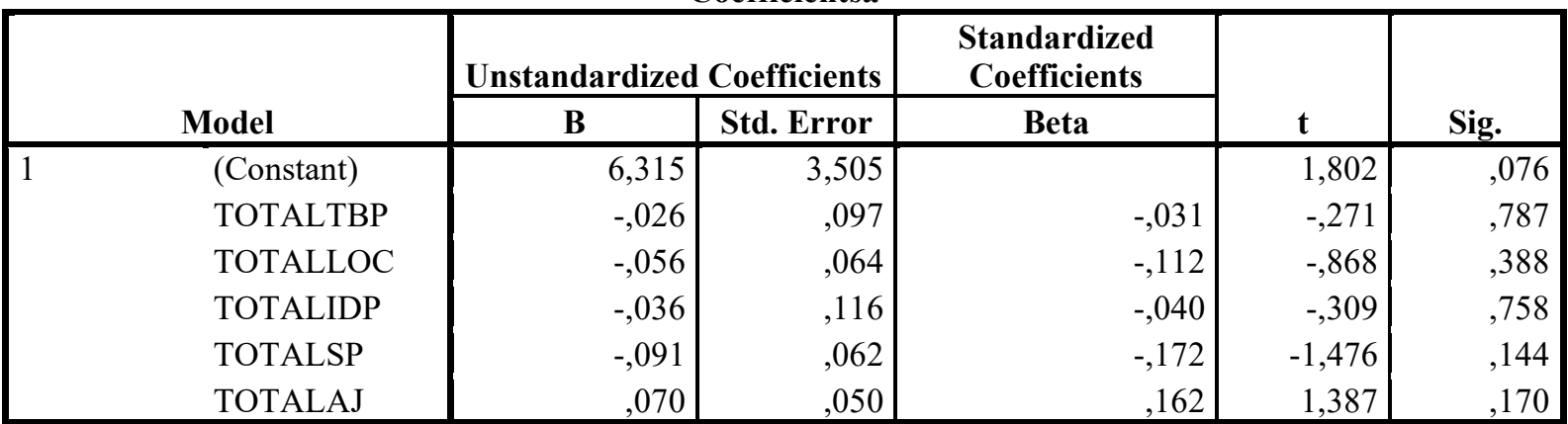

Source: SPSS Version 23

Based on the test results in table 3 above, it can be seen that the significant value of the independent variable is more than 0.05 . Thus it can be concluded that there is no problem of heteroscedasticity in the regression model. 
Table 4: Determination Coefficient Test Results Model Summary

\begin{tabular}{|l|r|r|r|r|}
\hline Model & R & R Square & Adjusted R Square & \multicolumn{1}{c|}{$\begin{array}{c}\text { Std. Error of the } \\
\text { Estimate }\end{array}$} \\
\hline 1 &, $748^{\mathrm{a}}$ &, 560 &, 530 & 3,112 \\
\hline
\end{tabular}

Source: SPSS Version 23

Based on table 4 , it is known that the adjusted $\mathrm{R}$ square value is 0.530 , which means that $53.0 \%$ of audit quality variables can be explained by the three independent variables namely time budget pressure, locus of control, independence, professional skepticism, and judgment audit. While the remaining $47.0 \%$ is influenced by other variables not explained in this study.

\section{Table 5: F Statistic Test Results}

ANOVA

\begin{tabular}{|r|r|r|r|r|r|}
\hline \multicolumn{1}{|c|}{ Model } & Sum of Squares & Df & Mean Square & \multicolumn{1}{c|}{ F } & Sig. \\
\hline Regression & 911,728 & 5 & 182,346 & 18,826 &, $000^{\mathrm{b}}$ \\
Residual & 716,760 & 74 & 9,686 & & \\
Total & 1628,488 & 79 & & & \\
\hline
\end{tabular}

Source: SPSS Version 23

Based on table $4.18 \mathrm{~F}$ count $=18.826$, df 1 (number of data groups- 1$)=3-1=2$, df $2=($ nk-1) or $(80-2-1)$ $=77$. The results obtained for $F$ table are 3.115 (See appendix table $\mathrm{f}$ ). $\mathrm{F}$ count $>\mathrm{F}$ table $(18,826>3,115)$ then Ho is rejected and $\mathrm{Ha}$ is accepted. The probability value (significant) is $0,000<0.05$ so there is a significant effect. It can be concluded that Time budget pressure, locus of control, independence, professional skepticism, and judgment audits simultaneously have a significant effect on audit quality.

Table 6: Individual Parameter Significance Test Results (T Test)

Coefficients $^{\mathrm{a}}$

\begin{tabular}{|ll|r|r|r|r|r|}
\hline \multirow{2}{*}{ Model } & \multicolumn{2}{|c|}{ Unstandardized Coefficients } & \multicolumn{2}{c|}{ Standardized Coefficients } & \multirow{2}{*}{ T } & Sig. \\
\cline { 2 - 6 } & \multicolumn{1}{c|}{ B } & Std. Error & Beta &, 450 &, 654 \\
(Constant) & 2,360 & 5,246 &,- 163 & $-2,081$ &, 041 \\
& TOTALTBP &,- 302 &, 145 &, 447 & 5,082 &, 000 \\
TOTALLOC &, 489 &, 096 &, 421 & 4,709 &, 000 \\
TOTALIDP &, 816 &, 173 &, 019 &, 234 &, 816 \\
TOTALSP &, 022 &, 092 &,- 014 &,- 177 &, 860 \\
\hline
\end{tabular}

Source: SPSS Version 23

Based on the table 6 time budget pressure has a significance value of $0.041<0.05$ and $t$ count $-2.081<$ 1.992 (-t count <-t table) so Ho is rejected Ha is accepted which means time budget pressure has a negative and significant effect on audit quality. Locus of control has a significance value of $0,000<0,05$ and t count 5,082 $>$ 1,991 ( $t$ count $>t$ table) then Ho is rejected Ha accepted that artinta locul of control has a positive and significant effect on audit quality. Independence has a significant value of $0,000<0,05$ and $t$ count 4,709>1,991 ( $t$ count $>t$ table) then Ho is rejected and $\mathrm{Ha}$ is accepted which means that independence has a positive and significant effect on audit quality. Professional skepticism has a significant value of $0.816>0.05$ and t count of $0.234<1.991$, so Ho is accepted and Ha is rejected, meaning professional skepticism has no effect and is not significant to audit quality. Audit Judgment has a significant value of $0.860>0.05$ and $t$ count of $-0.177>-1.992$ then Ho is accepted and $\mathrm{Ha}$ is rejected, which means that the judgment audit has no effect and is not significant to audit quality. Based on the table data above, it can be seen the results of the hypothesis test, as follows:

This shows that time budget pressure negative effect on audit quality. The result shows that the time budget pressure has a negative and significant effect on audit quality. This is consistent with McNamara and Liyanarachchi (2008) and Hutabarat (2012). This shows that the higher the time budget pressure received by the auditor, the lower the audit quality produced by the auditor. Because with a limited time budget, the auditor must tighten the programs implemented to be able to adjust to a limited time, so that the audit carried out cannot be carried out more carefully and carefully because of the budgeted time limit.

The results in the second hypothesis of this study indicate that locus of control has a positive influence on audit quality. This is in line with research conducted by Hyatt and Prawitt (2001), and Dennis M. Patten (2005). Someone who has a good locus of control auditor, the auditor's attitude has been combined by internal factors in him by conducting an audit process in accordance with applicable audit procedures. This shows that the higher the locus of control the higher the quality of the audit produced. an auditor who has a high locus of control tends to be more careful and more guided by the right way because if an auditor acts incorrectly such as making a 
deviation, the resulting audit results will not be of quality.

In testing the third hypothesis, Independence has a positive and significant influence on audit quality. This is in line with the research conducted by Deis, D.R. and G.A. Groux (1992), in undergoing the auditor's audit process combined with internal factors within him by trying to be honest and not affected by outsiders. This shows that the higher the level of independence possessed by an auditor, the higher the audit quality produced by the auditor. When an auditor has high independence, the auditor tends to provide opinions or conclusions in accordance with the actual conditions without the influence of the environment.

In testing the four hypothesis, based on the testing states that there is a positive influence in accordance with Fullerton and Durtschi (2004), which explains that an auditor must have a careful nature in the examination process and always heed the professional norms and prevailing moral norms. Similarly, the auditor's professional skepticism means that an auditor must be suspicious of the client, in order to be able to ask questions to obtain evidence competently, so that the evidence will strengthen the basis for conclusions contained in the auditor's opinion, related to audit quality in taking decision.

In testing the five hypothesis, explained that the Audit Judgment had an effect on audit quality in accordance with Iskandar (2010) and Wibowo's (2011) research. The exact or not the judgment auditor will determine the quality of the audit results and the opinions issued by the auditor. Audit Judgment determines the results of the audit implementation, namely opinions on the company's financial statements audited because the audit is not carried out on all the evidence. This evidence is used to provide Judgment on financial statements and audit quality.

\section{Conclusion}

Time budget pressure has a negative effect on audit quality. Then it can be concluded if the time budget pressure increases the audit quality decreases. Locus of control has a positive effect on audit quality. It can be concluded if the locus of control increases the audit quality increases. Independence has a positive effect on audit quality. It can be concluded if independence increases the audit quality increases. Professional skepticism has a positive effect on audit quality at the Republic of Indonesia BPK. Audit Judgment has a positive effect on Audit Quality at the Republic of Indonesia BPK. Suggestion It is expected that the auditor can improve competence by participating in training and has the ability to conduct audits to improve audit quality. The results of this study are expected to motivate future research to conduct further research related to audit quality.

\section{BIBLIOGRAPHY}

AAA Financial Accounting Standard Committee (2000), “Commentary: SEC Auditor Independece Requirements", Accounting Horizons Vol. 15 No. 4 December 2001, hal 373-386.

Arens, Alvin A., Elder, Randal J. \& Beasley, Mark S. 2005. Auditing an Assurance Service an Integrated Approach $10^{\text {th }}$ edition. New Jersey : Prentice Hall Internasional.

Bernardi, Richard A. 2003. Theoretical Model for the Relationship Among Stress, Locus of Control and Longevity. Inform Bussines Forum Research, 3 (4).

Coram, Paul, Ng, Juliana dan Woodliff, David. 2003. A Survey of Time Budget Pressure and Reduced Audit Quality Among Australia Auditors. Australia Accounting Review Vol.13 No. 1 : 38 - 44. 2004. The Effect of Time Budget Pressure Risk of Error on Auditor Performance. Departement of Accounting and Finance. The Universitiy of Western Australia.

Coram, Paul, Juliana Ng., dan David R. Woodlift (2004), "The Effect Of Risk of Misstatement on The Propensity to Commit Reduced Audit Quality Acts Under Time Budget Pressure", Auditing : A Journal Practice \& Theory. Vol.23, No 2, September, pp. 159-167.

Davidson, R.A., dan D. Neu. 1993. "A Note on The Association between Audit Firm Size and Audit Quality". Contemporary Accounting Research. 9 (Spring). pp. 479-488.

DeAngelo, Linda Elizabeth. 1981. Auditor Size And Audit Quality, Journal of Accounting and Economics:183199.

Deis, D.R. dan G.A. Groux. 1992. Determinants of Audit Quality in The Public Sector. The Accounting Review. Juli. p. 462-479

Donnelly, et al ,2003. "Auditor Acceptance of Dysfunctional Audit Behavior: An Explanatory Model Using Auditors' Personal Characteristics". Behavioral Research in Accounting, Vol 15.

Fullerton, Rosemary R., Cindy Durtschi. (2004). "The Effect of Professional Skepticsm on The Fraud Detection Skills of Internal Auditors". Jurnal Utah State University.

Hyatt, T.A. and Prawitt, D.F. (2001), "Does congruence between audit structure and auditors locus-of-control affect job performance?", The Accounting Review, Vol. 76 No. 2, pp. 263-74.

Hutabarat, Goodman. 2012. Effects of Time Budget Pressure and Experience Auditor Ethics on Audit Quality. 6th (1) ESAI Scientific Journal, January 2012 ISSN No. 1978-6034

Ikatan Akuntan Indonesia. Kompartemen Akuntan Publik, 2001, Standar Profesional Akuntan Publik, per 1 
Januari 2001, cetakan ke-1, PT. Salemba Empat, Jakarta.

Iskandar Takiah Mohd, Ria N.S.Zuraidah M.S and Rita A. 2010. Enchanging Auditor Judgment Through Motivational Factors. Discussion Paper Publisher, Faculty of Economics and commerce.

Kaplan, Steven E. (1995). An Examination of Auditors' Reporting Intentions Upon Discovery of Procedures Prematurely Signed-Off. Auditing : A Journal of Practice and Theory.

Kasus suap auditor BPK (2016). Sumber kompas.com 11/10/2017. (https://nasional.kompas.com/read/2017/10/11/16054571/kasus-suap-auditor-bpk-dua-pejabat-kemendesdituntut-2-tahun-penjara).

Kinney, W.R. 1999. “Auditor Independence: A Burdensome Constraint or Core Value?”. Accounting Horizons. 13 (1). pp. 69-75.

Loebbecke, J., M. Eining, and J. Willingham. 1989: Auditors experience with material irregularities : Frequency, nature, and detect ability. Auditing : A Journal of Practice \& Theory 9 (Fall) : 1-28.

Liayanarachchi, dan Mc Namar, 2007, Time Budget Pressure in New Zeaand Audits, Bussiness Review Volume 9 No.2, The University of Auckland.

Mayangsari, Sekar. 2003. Effects of Expertise and Independence on Opinion Audit: An Experiment. Indonesian Accounting Research Journal, 6 (1) (January).

McNamara, Shaun M and Gregory A Liyanarachchi. 2008. Time budget pressure and auditor dysfunctional behaviour within an occupational stress model. Accountancy Business and the Public Interest, 7(1).

Messier, F.W., V.S. Glover, and F.D. Prawitt. 2005. Audit and Assurance Services: A Systematic Approach.

Nurlis, 2018. The Effect of The Government Accounting Standards Implementation and Apparatus Competency on the Quality of the Local Government Financial Reporting (Case Study at Klaten District Government). Research Journal of Finance and Accounting ISSN 2222-1697 (Paper) ISSN 2222- 2847. Vol.9, No.8, 2018.

Patten, M. Dennis. (2005), “An Analysis of The Impact of Locus of Control on Internal Auditor Job Performance and Satisfaction”, Managerial Auditing Journal, Vol. 20 No. 9, pp. 1016-1029.

Setiyawati, Hari., "The effect of Internal Accountants' Competence, Managers' Commitment to Organizations and the Implementation of the Internal Control System on the Quality of Financial Reporting", International Journal of Business and Management Invention, www.ijbmi.org, Volume 2 Issue 11, PP.19-27, November 2013

Waggoner dan Cashell. (1991). The Impact of Time Pressure on Auditor's. CPA Journal.

Watkins, A.L. W. Hillison, dan S.E. Morecroft. 2004. "Audit Quality: A Synthesis of Theory and Empirical Evidence”. Journal of Accounting Literature. 23. pp. 153-193.

Wibowo, Eri. 2011. Learning Analysis Auditing Courses (Competence in Audit Judgment). Maximum Volume 1 No.2. 